UNSUR KAWALAN DAN ORGANISASI PENAUNG AKTIVITI PENTERJEMAHAN AL-QUR'AN DI MALAYSIA ${ }^{(*)}$

\title{
Control Elements and its Patronal Organizations in the Activity of Quranic Translation in Malaysia
}

\section{Kasyfullah A. Kadir ${ }^{1} \&$ Idris Mansor ${ }^{2}$}

\begin{abstract}
ABSTRAC'T
As a sacred text for Muslims, the Holy Qur'an contains many sensitive features that need to be carefully dealt with when translating it into other languages. This is to preserve the content of the Qur'an from errors and manipulations. As such, control mechanisms and patronage need to come into play in order to regulate translations of the Qur'an. This article studied and discussed control mechanisms for Qur'an translations employed in Malaysia, and it also looked into the organizations involved in this effort. To achieve these objectives, this study has examined a number of documents. The findings are also further supported by data from interviews. The study found that Malaysia enforces regulations on Qur'an translation activities through statutes, enactments, guidelines and Islamic legal rulings. The organizations involved in the regulations are the Ministry of Home Affairs, aided by the representative of the Prime Minister's Office, the Department of Islamic Development Malaysia, as well as state religious authorities and the Fatwa Committee of the National Council for Islamic Religious Affairs in Malaysia.
\end{abstract}

Keywords: Qur'an translation; Control; Patronage; Organization; the Malay language..

() This article was submitted on: 27/07/2016 and accepted for publication on: 04/11/2016.

1 Pusat Pendidikan Asas dan Liberal, Universiti Malaysia Terengganu, kasyfullah.kadir@umt.edu.my

${ }^{2}$ Senior Lecturer, School of Humanities, Universiti Sains Malaysia, Email: idrismansor@usm.my 


\section{ABSTRAK}

Sebagai sebuah teks suci yang menjadi pegangan umat Islam, al-Qur'an mempunyai ciri-ciri sensitif yang perlu diambil perhatian dalam proses menterjemahkannya ke dalam bahasa-bahasa yang lain. Hal ini demikian bagi mengelakkan daripada kesalahan serta penyelewengan terjemahan. Oleh yang demikian, unsur-unsur kawalan dan naungan perlu diimplementasi dalam kerja-kerja terjemahan teks al-Qur'an. Artikel ini meneliti dan membincangkan unsur-unsur kawalan dalam penterjemahan al-Qur'an di Malaysia dan organisasi-organisasi yang terlibat. Bagi tujuan tersebut, sebuah penyelidikan yang berdasarkan kajian dokumen yang disokong oleh data temubual telah dijalankan. Kajian ini mendapati Malaysia melakukan kawalan terhadap aktiviti terjemahan al-Quran berasaskan akta, enakmen, garis panduan dan fatwa. Adapun organisasi yang terlibat dalam mengawal selia aktiviti ini pula ialah Kementerian Dalam Negeri (KDN) dengan kerjasama Jabatan Perdana Menteri (JPM) yang diwakili oleh Jabatan Kemajuan Islam Malaysia (JAKIM), pihak berkuasa agama peringkat negeri dan juga Jawatankuasa Fatwa Majlis Kebangsaan Bagi Hal Ehwal Ugama Islam Malaysia.

Kata Kunci: Terjemahan al-Quran; Kawalan; Naungan; Organisasi; Bahasa Melayu.

\section{PENGENALAN}

Sejarah awal aktiviti penterjemahan al-Quran yang diusahakan oleh para orientalis telah menghasilkan produk terjemahan al-Qur'an yang sarat dengan pelbagai kesalahan. Kesalahan-kesalahan terjemahan ini telah dibincangkan dengan terperinci oleh Muhammad Khalifa (1989: 64-79) dan Muhammad Mohar Ali (2004: 324356). Terjemahan al-Qur'an yang pertama yang diusahakan oleh Peter the Venerable ke dalam bahasa Latin yang disempurnakan oleh Robertus Rosenesis dan Hermannus Dalmata pada tahun 1143 adalah bertujuan untuk menyalahkan Islam (Ali, 2004: 324). Selain itu, terjemahan al-Quran yang dihasilkan oleh Goerge Sale pada tahun 1734 merupakan terjemahan ke dalam bahasa Inggeris yang masyhur tetapi mempunyai banyak kesalahan terjemahan. Walau bagaimanapun, hasil terjemahan ini dijadikan sebagai panduan untuk proses penterjemahan ke dalam bahasa-bahasa yang lain seperti bahasa Belanda pada tahun 1742, bahasa Perancis pada tahun 1750, bahasa Jerman pada tahun 1764, bahasa Rusia pada tahun 1792, bahasa Sweden pada tahun 1814 dan bahasa Bulgaria pada tahun 1902 (Khalifa 1989: 65). 
Menurut al-Zarqani (1988: 2/116-117), al-Quran telah diterjemahkan ke dalam pelbagai bahasa di dunia sehingga mencapai jumlah 120 terjemahan yang merangkumi 35 bahasa negara timur dan bahasa negara barat. Hasil terjemahan yang paling banyak ialah terjemahan dalam bahasa-bahasa Eropah iaitu bahasa Inggeris, bahasa Perancis, bahasa Jerman dan bahasa Itali. Malangnya, hasil terjemahan ini banyak mengandungi kesalahan yang sangat jelas yang dilihat sebagai sengaja dilakukan bagi tujuan untuk merosakkan Islam serta memporakperandakan kesatuan bahasa dan umat Islam. Pendapat ini turut disokong oleh Atabik Luthfi (2004: 38) dan Mohd Shukri Hanapi (2003: 91) yang berpendapat bahawa sebahagian besar hasil terjemahan ini mengandungi kesalahan besar yang boleh merosakkan akidah umat Islam.

Wherry (1882/2001: 6) pula berpendapat bahawa aktiviti penterjemahan alQuran yang banyak ini merupakan tindak balas negara barat terhadap perkembangan pengaruh Islam yang semakin meluas. Justeru, kebanyakan hasil terjemahan yang dibuat oleh penterjemah yang bukan Islam agak sukar untuk dipercayai kebenarannya. Penyelewengan ini terjadi dengan berleluasa kerana tiada mekanisme kawalan dan garis panduan khusus dalam penterjemahan al-Qur'an.

Hal ini demikian kerana usaha penterjemahan al-Qur'an pada peringkat awalnya tidak dilakukan oleh orang Islam sendiri yang memiliki kemahiran yang lebih baik dalam bahasa Arab serta lebih memahami selok belok yang terdapat dalam agama Islam. Perkara ini disebabkan oleh terjemahan al-Qur'an dahulunya telah diharamkan oleh para ulama silam. Namun, memandangkan penyebaran al-Quran yang diusahakan oleh orientalis ini sudah tidak terkawal, para ulama Islam kembali membincangkan mengenai larangan penterjemahan al-Quran ke dalam bahasabahasa yang lain. Para ulama Islam kemudiannya bersepakat mengharuskan penterjemahan al-Qur'an. Usaha terawal dilakukan oleh Mustafa al-Maraghi pada tahun 1936 yang dipersetujui oleh barisan ulama al-Azhar (Atabik Luthfi, 2004: 3839).

Di Malaysia juga, aktiviti penterjemahan al-Qur'an ke dalam bahasa Melayu turut giat dijalankan. Usaha terawal menggunakan pendekatan terjemahan secara literal, yang juga dikenali sebagai terjemahan harfiyyah. Namun, pendekatan tersebut kemudiannya digantikan dengan terjemahan yang lebih memberi fokus kepada makna. Beberapa teks terjemahan al-Qur'an telah diterbitkan, antara yang terkenal dan tersebar luas ialah Tafsir Pimpinan Ar-Rahman yang diselenggarakan oleh Abdullah Basmeih yang mula diusahakan pada tahun 1957 (Sejarah Jakim, 2005). Namun begitu, memandangkan aktiviti penterjemahan merupakan sebuah aktiviti yang agak bebas, terdapat juga hasil terjemahan al-Qur'an ke dalam bahasa Melayu yang menyeleweng. Antaranya ialah terjemahan al-Qur'an yang bertajuk 'Bacaan' 
yang dihasilkan oleh Othman Ali. Teks terjemahan ini telah diharamkan oleh kerajaan Malaysia pada 22 Julai 1995 dengan kod pengharaman P.U.(A)261.

Selain itu, terdapat juga penerbitan terjemahan al-Qur'an yang didapati mempunyai kesalahan-kesalahan tertentu seperti 'Al-Qur'an Terjemahan Dwi Bahasa: Melayu dan Inggeris' yang diterbitkan oleh Yayasan Felda yang terpaksa ditarik balik kelulusan penerbitannya disebabkan terdapat dua kesalahan, iaitu terdapat ayat yang tidak disalin secara lengkap yang melibatkan Ayat 8 Surah Yusuf, dan terdapat pengguguran Ayat 116 Surah al-Ancam di samping pengulangan Ayat 117 (Mohd. Firdaus Che Daud, temubual, 20 Oktober 2015). Begitu juga teks alQur'an dan terjemahan perkata terbitan Syarikat Magfirah Pustaka al-Madani yang turut dikenal pasti kesilapan kerana terdapat pengulangan ayat terjemahan pada Ayat 27 Surah Ali 'Imran yang boleh menyebabkan pembaca keliru tentang maksud sebenar ayat al-Qur'an (Mohd Hasbie al-Shiddieque \& Khairul Anuar Mohamad 2015: 7).

Situasi sebegini memperlihatkan keperluan kepada pengawalan dalam aktiviti penterjemahan al-Qur'an. Pengawalan terhadap aktiviti ini amat penting memandangkan al-Qur'an merupakan teks suci agama Islam yang kandungannya adalah bersifat sensitif. Kebanyakan umat Islam di Malaysia hanya bergantung kepada teks terjemahan al-Qur'an untuk memahami kandungan teks suci tersebut. Sekiranya aktiviti terjemahan al-Qur'an tidak dikawal, maka dikhuatiri kefahaman, pegangan bahkan akidah pembaca akan terseleweng.

Berdasarkan permasalahan ini, satu kajian telah dijalankan bagi mengenal pasti unsur-unsur kawalan aktiviti penterjemahan al-Qur'an di Malaysia dan organisasi-organisasi yang terlibat dalam proses pengawalan tersebut. Kajian ini dijalankan dengan menggunakan pendekatan kajian dokumen dan disokong oleh dapatan temubual. Kajian dokumen meliputi teks-teks akta yang digezetkan oleh kerajaan Malaysia, garis panduan yang dikeluarkan oleh Kementerian Dalam Negeri, Malaysia dan Jabatan Kemajuan Islam Malaysia. Adapun temubual melibatkan dua pegawai yang terlibat secara langsung dengan aktiviti kawalan teks terjemahan alQur'an, iaitu seorang kakitangan di Jabatan Kemajuan Islam Malaysia, dan seorang kakitangan Kementerian Dalam Negeri, Malaysia.

\section{KONSEP KAWALAN DAN NAUNGAN DALAM PENTERJEMAHAN}

Andre Lefevere (1992) dalam bukunya Translation, Rewriting and the Manipulation of Literary Fame, telah memperkenalkan teori terjemahan sebagai penulisan semula (rewriting). Melalui teori ini, Lefevere percaya bahawa terjemahan merupakan sebuah 
aktiviti penulisan semula kerana berpotensi menjelmakan semula imej penulis asal dan hasil kerjanya di luar ruang lingkup budaya yang asal (Lefevere 1992: 9).

Melalui teori ini, Lefevere sebenarnya memberi fokus terhadap proses mengenal pasti faktor-faktor yang kukuh yang mempengaruhi sambutan, penerimaan dan penolakan terhadap sesebuah teks, iaitu "issues such as power, ideology, institution and manipulation" (Lefevere, 1992: 2). Menurut Lefevere, penulisan sesebuah teks dipengaruhi oleh dua faktor utama, iaitu 1) profesional dalam sistem penulisan, dan 2) naungan (patronage) yang berada di luar sistem penulisan. Naungan merujuk "the powers (persons, institutions) that can be further or hinder the reading, writing, and rewriting of literature" (Lefevere 1992: 15). Munday (2012: 195) memberi perincian bahawa penaung bagi sesuatu proses penterjemahan terdiri daripada:

a. individu yang berkuasa dan berpengaruh dalam sesuatu zaman (contohnya: Elizabeth 1 dalam penterjemahan teks Shakespeare dan Hitler dalam aktiviti penterjemahan di Jerman sekitar tahun 1930an).

b. kumpulan individu yang terdiri daripada penerbit, media dan parti politik).

c. institusi yang terlibat secara langsung dengan proses penyebaran hasil penulisan seperti akademi penulisan negara (di Malaysia dikenali sebagai Dewan Bahasa dan Pustaka), jurnal-jurnal akademik dan yang paling utama agensi-agensi kerajaan terutama yang berkaitan dengan pendidikan.

Konsep naungan ini dilihat diamalkan di Malaysia, khususnya terhadap teks yang berkaitan dengan agama rasmi negara, iaitu agama Islam termasuk aktiviti penterjemahan dan penyebaran teks terjemahan al-Qur'an. Proses kawalan dan naungan ini bertepatan dengan prinsip taqyid mubah iaitu salah satu prinsip dalam perundangan Islam. Prinsip ini memberi ruang kepada pemerintah untuk mewujudkan naungan terhadap aktiviti-aktiviti yang berkaitan dengan kepentingan rakyat (Zulkifly bin Muda\& Nizaita binti Omar, 2010: 95).

Dalam konteks terjemahan al-Qur'an di Malaysia, aktiviti tersebut dikawal sepenuhnya oleh kerajaan Malaysia. Kawalan dan naungan ini diamalkan di Malaysia bertujuan untuk memastikan bahawa teks-teks yang berkaitan dengan akidah dan pegangan umat Islam di Malaysia terhindar daripada sebarang kesilapan dan penyelewengan. Rentetan daripada itu, produk yang mempunyai kesilapan, kesalahan dan bercanggah dengan dasar negara dilarang daripada diterbitkan. Setakat ini, telah ada hasil terjemahan lengkap yang telah diharamkan penggunaannya oleh Kerajaan Malaysia melalui Kementerian Dalam Negeri kerana tidak menepati syarat-syarat 
percetakan dan penterjemahan al-Quran yang telah digariskan oleh perundangan negara.

\section{AKTIVITI TERJEMAHAN AL-QUR'AN DI MALAYSIA}

Berdasarkan pemerhatian, aktiviti penterjemahan al-Qur'an di Malaysia boleh dibahagikan kepada tiga kategori: i) terjemahan persendirian, ii) terjemahan komersial, dan iii) terjemahan kerajaan.

\section{Terjemahan Persendirian}

Usaha untuk menterjemah al-Quran di Malaysia mula dipelopori oleh pihak persendirian, iaitu aktiviti penterjemahan al-Qur'an yang dilakukan atas dasar sukarela, sama ada secara individu ataupun berkumpulan. Menurut Mohd Shukri Hanapi (2003: 131\&144) kaedah terjemahan yang mula-mula digunakan ialah kaedah harfiyyah yang diperkenalkan oleh Muhammad Ma'adah bin Layang pada tahun 1937 di Negeri Sembilan. Walaupun usaha penterjemahan ini telah diusahakan sejak dari sebelum merdeka lagi, namun tidak ada hasil yang diterbitkan sehinggalah pada tahun 1975 Hashim Abdul Ghani berjaya menyiapkan terjemahan lengkap sebanyak 30 juzuk. Walau bagaimanapun, hasil terjemahan tersebut hanya diterbitkan secara rasmi pada tahun 1991 oleh Institut Kursus Terjemahan al-Furqan (KTF Institute) Kuala Pilah, Negeri Sembilan berjudul 'Induk Kamus Pelajaran Menterjemah al-Quran'.

Antara terjemahan lain yang pernah diterbitkan juga ialah 'Al-Quran Bergantung Makna Jawi Bagi Bacaan Anak-anak Sehari-hari' hasil terjemahan Abdullah bin Haji Abbas Nasution. Terjemahan ini siap diterjemah pada tahun 1948 menggunakan tulisan jawi dalam bahasa yang ringkas. Laras bahasa sebegini bersesuaian dengan tujuan penghasilannya untuk kegunaan kanak-kanak. Kaedah terjemahan yang digunakan ialah harfiyyat bi dun al-Mithl iaitu kaedah terjemahan langsung dan tidak disertai sebarang huraian. Terjemahan ini dicetak kali pertamanya pada tahun 1956 sebanyak 15 juzuk sahaja. Terbitan lengkap 30 juzuk hanya diterbitkan pada tahun 1968 oleh Maktabah Haji Abdullah bin Muhammad Nuruddin al-Rawiy yang bertempat di Pulau Pinang dengan belanja 65 ribu ringgit (Mohd Shukri Hanapi 2003: 134).

Selain daripada terjemahan lengkap yang meliputi keseluruhan 30 juzuk yang terkandung dalam al-Qur'an, terdapat juga beberapa terjemahan yang dilakukan secara sebahagian. Antaranya ialah a) Tafsir al-Quran al-Karim Juzu' Amma yang dihasilkan oleh Mohd Fauzi Haji Awang dan diterbitkan oleh Pustaka Aman Press, 
Kelantan pada tahun 1964 (Mohd Fauzi Haji Awang, 1964:4-5), b) Terjemahan Juzu’ Amma Secara Harfiah, hasil terjemahan Rusman Adsyah terbitan Darul Nu’man, Kuala Lumpur pada tahun 1995 (Rusman Adsyah, 1995: i).

Walaupun hasil-hasil terjemahan adalah usaha persendirian dan tidak diterbitkan secara rasmi oleh kerajaan Malaysia, tetapi kandungannya telah pun disemak terlebih dahulu oleh Lembaga Pengawalan dan Pelesenan Pencetakan alQuran (LPPPQ) sebelum diberi kelulusan oleh Kementerian Dalam Negeri Malaysia.

\section{Terjemahan Kerajaan}

Penterjemahan al-Qur'an oleh pihak kerajaan bermaksud penterjemahan yang sama ada diusahakan oleh kerajaan, atau membabitkan agensi kerajaan, atau menggunakan dana kerajaan serta kepakaran daripada pihak kerajaan. Sehingga ke hari ini, tidak banyak terjemahan al-Quran yang diterbitkan secara rasmi oleh kerajaan Malaysia. Antara terjemahan yang pernah diterbit serta diguna pakai secara meluas di Malaysia ialah Tafsir Pimpinan Ar-Rahman Kepada Pengertian Al-Quran (TPA). TPA pada awalnya adalah hasil terjemahan Faisal Haji Othman yang kemudiannya diteruskan oleh Abdullah bin Muhammad Basmeih. TPA ini adalah merupakan projek kerajaan Malaysia yang telah bermula seawal tahun 1957 (Sejarah Jakim, 2005).

TPA merupakan terjemahan al-Quran pertama menggunakan bahasa Malaysia moden dan mudah difahami. Pada asalnya teks terjemahan ini terbahagi kepada tiga jilid yang diterbitkan secara berasingan dan berturutan. Jilid pertama diterbitkan pada tahun 1968, jilid kedua diterbitkan pada tahun 1970 dan jilid ketiga diterbitkan pada tahun 1972 ("Tafsir Pimpinan Ar-Rahman dalam Bentuk Baru," 1998). TPA kemudiannya diterbitkan sebagai sebuah jilid yang lengkap oleh Bahagian Hal Ehwal Islam di Jabatan Perdana Menteri dalam dua versi, iaitu versi tulisan rumi pada tahun 1980 dan versi tulisan jawi pada tahun 1983 (Wan Ramizah 2000: 214-216).

Selain TPA, terjemahan al-Quran ke dalam bahasa Melayu yang pernah diterbitkan secara rasmi oleh kerajaan Malaysia ialah Al-Quran Al-Karim: Terjemahan dan Huraian Maksud (THM) yang dihasilkan oleh Muhammad Uthman El-Muhammady. Terjemahan ini dicetak buat kali pertamanya pada tahun 1992 dan diterbitkan oleh Dewan Bahasa dan Pustaka, Kuala Lumpur. THM merupakan terjemahan al-Qur'an yang dihasilkan berdasarkan medium terjemahan al-Qur'an bahasa Inggeris yang diterjemahkan oleh Abdullah Yusuf Ali (Muhammad Uthman El-Muhammady, 1992: xi). 
Teks terjemahan ini diterbitkan tanpa melalui tapisan KDN. Namun begitu, disebabkan oleh tiada aduan dan kesilapan yang berlaku pada teks ini, maka penyebarannya tidak dihalang di negara ini.

\section{Terjemahan Komersial}

Terjemahan al-Qur'an secara komersial bermaksud usaha yang dilakukan oleh pihak tertentu dengan tujuan pasaran yang berasaskan keuntungan. Pada masa ini, aktiviti terjemahan dalam kategori komersial berada dalam suasana yang baik dengan lahirnya pelbagai terjemahan di pasaran (Azani Ismail @ Yaakub et.al 2014: 542). Antara terjemahan tersebut ialah Al-Quran Rasm Uthmani Bertajwid dan Disertai Makna, At-Tanzil Terjemahan al-Hidayah al-Qur'an al-Karim (Rasm Uthmani), Terjemahan Bahasa Melayu al-Quran al-Karim Berserta Tajwid, Indeks Kata \& Indeks Peristiwa, al-Quran al-Karim dan Terjemahan Lafziyyah (per-kata), al-Quran Mushaf Tajwid Berserta Terjemahan ke dalam Bahasa Malaysia dan banyak lagi.

Berdasarkan pemerhatian, kebanyakan terjemahan komersial ini merujuk kepada sama ada hasil terjemahan sedia ada seperti Tafsir Pimpinan Ar-Rahman atau teks terjemahan al-Qur'an dalam bahasa Indonesia yang kemudiaannya diubah suai bahasanya agar bersesuaian dengan bahasa Melayu di Malaysia. Pihak penerbit melalui ahli-ahli panel penyemak akan membuat perubahan daripada sudut penggunaan istilah agar sesuai dengan perkembangan semasa. Selain daripada itu, penerbit juga akan menambah maklumat-maklumat tertentu seperti hadis-hadis yang berkaitan dengan sebab-sebab turunnya ayat ataupun hukum-hukum fekah yang berkaitan dengan wanita sebagai satu usaha untuk menarik minat pembeli membeli produk tersebut.

Dalam kategori terjemahan al-Qur'an secara komersial juga, terdapat penerbit yang mensasarkan golongan bukan Islam sebagai pembaca. Justeru, terjemahan al-Qur'an yang dihasilkan adalah berbahasa Melayu sepenuhnya tanpa disertakan teks al-Qur'an. Hal ini demikian bagi membolehkan golongan bukan Islam untuk memiliki dan membaca teks tersebut. Rentetan daripada itu, sebuah produk terjemahan yang berjudul 'Terjemahan al-Quran bahasa Melayu' yang diterbitkan oleh penerbit Al-Madinah, Kuala Lumpur telah berjaya diterbitkan. Usaha ini walau bagaimanapun bercanggah dengan syarat penerbitan teks terjemahan al-Qur'an di Malaysia yang perlu disertakan teks al-Qur'an bersama dengan teks terjemahan. Hasil daripada aduan orang awam, 'Terjemahan al-Quran bahasa Melayu' diharamkan penerbitannya dan diperintah supaya menarik balik penerbitan yang telah berada di pasaran (Mohd Firdaus Che Daud, temu bual, 20 Oktober 2015). 


\section{KAWALAN TERHADAP AKTIVITI PENERBITAN DAN PENTERJEMAHAN AL-QURAN}

Kawalan terhadap aktiviti penterjemahan al-Qur'an di Malaysia melibatkan beberapa unsur kawalan seperti akta, enakmen dan garis panduan. Proses pengawalan ini di kawal selia oleh beberapa organisasi iaitu Kementerian Dalam Negeri, Malaysia (KDN), Jabatan Kemajuan Islam Malaysia (JAKIM), pihak berkuasa agama negeri dan Majlis Fatwa Kebangsaan.

\section{Unsur-unsur Kawalan al-Qur'an}

Hasil daripada penelitian yang dijalankan terhadap beberapa dokumen dan temu bual mendapati beberapa unsur terlibat secara langsung dalam proses pengawalan aktiviti penterjemahan al-Qur'an dan penerbitan teks terjemahan al-Qur'an. Unsur-unsur kawalan tersebut terdiri daripada beberapa akta yang telah digezetkan oleh kerajaan Malaysia, enakmen dan ordinan, beberapa garis panduan dan fatwa.

\section{I) Akta}

Akta bermaksud undang-undang yang digubal dan diluluskan oleh parlimen (Kamus Dewan 2010). Penggubalan akta perlu melalui beberapa proses di parlimen seperti perbahasan di Dewan Rakyat dan Dewan Negara serta disahkan oleh Seri Paduka Baginda Yang di-Pertuan Agong.

Kaedah penggubalan akta-akta ini dinyatakan dalam bahagian pendahuluan sebagaimana berikut:

maka inilah diperbuat undang-undang oleh Seri Paduka Baginda Yang diPertuan Agong dengan nasihat dan persetujuan Dewan Negara dan Dewan Rakyat yang bersidang dalam Parlimen dan dengan kuasa daripadanya... (Akta Pencetakan Teks al-Quran, 2008: 5)

Hal ini menjadikan akta yang digubal oleh parlimen sebagai sebuah undang-undang yang sah dan luhur. Oleh itu, semua akta yang telah diwartakan oleh kerajaan wajib dipatuhi oleh semua pihak di Malaysia.

Terdapat dua akta utama yang menaungi aktiviti percetakan al-Quran di Malaysia iaitu a) Akta 301 - Akta Mesin Cetak Dan Penerbitan 1984 (AMCP) dan b) Akta 326 - Akta Pencetakan Teks al-Quran 1986 (APTQ). 


\section{i) Akta 301 - Akta Mesin Cetak dan Penerbitan 1984 pindaan 1987 (AMCP)}

AMCP secara umumnya berfungsi untuk mengawal selia penggunaan mesin cetak dan percetakan, pengimportan, penghasilan semula, penerbitan dan pengedaran hasil penerbitan dan perkara-perkara yang berkaitan (AMCP, 2003: 5).

Secara khususnya, AMCP digubal bagi menghalang penyalahgunaan mesin cetak terutamanya terhadap 'hasil penerbitan larangan' atau disebut juga sebagai 'hasil penerbitan tak diingini'. Sesuatu bahan penerbitan dianggap sebagai hasil penerbitan larangan sekiranya mengandungi unsur-unsur yang memudaratkan orang ramai dan bercanggah dengan undang-undang negara. Adapun kandungan dan bentuk-bentuk penerbitan di jelaskan pada Seksyen 7 subseksyen (1) bahagian IV: Kawalan Hasil Penerbitan Tak Diingini:

...apa-apa hasil penerbitan mengandungi apa-apa makalah, karikatur, fotograf, laporan, nota, tulisan, bunyi, muzik, kenyataan atau apa-apa perkara lain yang mengikut apa-apa jua cara memudaratkan atau mungkin memudaratkan ketenteraman awam, kemoralan, keselamatan atau mungkin menggemparkan fikiran orang ramai atau yang berlawanan atau mungkin berlawanan dengan mana-mana undang-undang atau yang selainnya memudaratkan atau mungkin memudaratkan kepentingan awam atau kepentingan negara... (AMCP, 2003: 10)

Pewartaan terhadap AMCP menjadikan al-Quran dan terjemahannya sebagai bahan yang dikawal. Kawalan ini bermaksud pengawasan kerajaan terhadap tulisan dan terjemahan al-Quran supaya kandungannya menepati kehendak Islam dan dasardasar kerajaan. Hal ini perlu diwujudkan kerana penulisan dan penterjemahan alQuran yang bercanggah dengan Islam dan dasar kerajaan boleh mengelirukan fikiran orang ramai serta memudaratkan ketenteraman awam. Kawalan juga mampu mengelakkan penyelewengan terhadap makna al-Quran serta boleh merosakkan kesucian Islam yang menjadi anutan majoriti rakyat Malaysia. Malah, pemeliharaan kesucian al-Quran dan Islam adalah salah satu tanggungjawab kerajaan yang disebut dalam perlembagaan negara yang mengiktiraf Islam sebagai agama rasmi Malaysia.

Kawalan penerbitan sebegini bukan sahaja merangkumi produk dalam negara malah melibatkan juga produk-produk luar negara sebagaimana yang dinyatakan dalam seksyen 7 Hasil Penerbitan Larangan (2).

...(2) Berkenaan dengan hasil penerbitan yang bermula di mana-mana negara di luar Malaysia, satu perintah di bawah subseksyen (1) boleh, jika perintah itu 
memperuntukkan sedemikian: a) melarang pengimportan mana-mana atau semua hasil penerbitan sama ada sebelum atau selepas tarikh perintah itu, dengan tertakluk kepada apa-apa syarat yang ditetapkan di dalamnya. (AMCP, 2003: 10-11)

Dalam hal ini, penerbitan al-Quran yang tidak bertepatan dengan dasar kerajaan Malaysia dan terjemahan yang bertentangan dengan pegangan akidah ahli sunah waljamaah samada keluaran tempatan ataupun diimport adalah tertakluk di bawah kategori 'Hasil Penerbitan Larangan' (Mohd Firdaus Che Daud, temu bual, 20 Oktober 2015).

\section{ii. Akta Pencetakan Teks al-Quran 1986 (APTQ)}

APTQ telah mendapat pengesahan Seri Paduka Baginda Yang Dipertuan Agong pada 7 Mei 1986 dan disiarkan dalam warta pada 19 Mei 1986. Menurut Aminuddin Ali (2015), masalah berkaitan percetakan al-Quran mula diketengahkan apabila wujudnya al-Quran yang mempunyai kesilapan percetakan seperti hilang perkataan dan ayat-ayat tertentu. Permasalahan ini telah berlaku secara berleluasa sehingga beberapa aduan telah dibuat oleh orang ramai kepada pihak kerajaan. Rentetan daripada itu, kerajaan menggubal sebuah akta khusus bagi memelihara kesucian al-Quran dan dinamakan sebagai 'Akta Pencetakan Teks al-Quran 1986' (Panduan Rasm Uthmani, 2012: 107).

Tujuan penggubalan APTQ ialah untuk mengawal aktiviti yang berkaitan dengan 'teks al-Quran' dan 'bahan al-Quran'. Hal ini dijelaskan di dalam APTQ sebagaimana pernyataan berikut:

suatu akta untuk mengawal pencetakan, pengimportan, penjualan, penerbitan dan pengedaran teks al-Quran dan bahan al-Quran dan untuk membuat peruntukan mengenai perkara-perkara yang berhubungan. (APTQ, 2008: 5).

'Teks al-Quran' dalam pernyataan ini bermaksud ayat al-Quran yang ditulis dalam bahasa Arab. Keadaan teks al-Quran yang dikawal diperincikan dalam APTQ sebagaimana pernyataan berikut:

'ayat al-Quran' pula meliputi mana-mana bahagian ayat al-Quran dalam bahasa Arab...(APTQ, 2008: 5).

Adapun 'bahan al-Quran' pula bermaksud sesuatu dokumen yang mengandungi mana-mana ayat al-Quran (APTQ, 2008: 5). Dokumen-dokumen 
yang mengandungi ayat al-Quran sama ada bersama terjemahan atau pun tidak adalah tertakluk kepada kawalan. Hal ini dijelaskan dalam pernyataan berikut:

sesuatu dokumen yang mengandungi teks bahasa Arab yang lengkap bagi alQuran atau mana-mana bahagiannya yang mengandungi satu juzu' atau lebih sama ada dengan terjemahan atau tafsiran atau tidak... (APTQ, 2008: 7)

Perenggan seterusnya memperincikan lagi bentuk-bentuk dokumen yang mengandungi ayat-ayat al-Qur'an yang perlu dikawal:

'dokumen' ertinya apa-apa hal yang dinyatakan, diperihalkan, atau bagaimana jua pun digambarkan, atas apa-apa hal yang terkandung dalam cakera, pita, filem, runut bunyi atau apa jua pun peranti lain, dengan menggunakan:

- Huruf, angka, tanda, simbol, isyarat, lambang, atau apa jua pun bentuk pernyataan, perihalan, atau gambaran lain;

- Apa-apa rakaman tampak (sama ada imej kaku atau bergerak);

- Apa-apa rakaman bunyi, atau apa-apa jua pun rakaman elektronik, magnetik, mekanikal atau rakaman lain dan walau bagaimana jua pun di buat, atau apaapa bunyi, dedenyut elektronik, atau apa jua pun data lain;

- Suatu rakaman, atau pemancaran, dari suatu jarak, apa-apa hal dengan manamana, atau apa-apa gabungan, cara yang disebut dalam perenggan a), b) atau c),

- Atau dengan lebih daripada satu cara yang disebut dalam perenggan a), b), c) dan d), yang dimaksudkan untuk digunakan atau yang mungkin digunakan bagi tujuan menyatakan, memperihalkan, atau dengan apa jua cara sekalipun menggambarkan hal itu. (APTQ, 2008: 6)

Berdasarkan kepada pernyataan ini, dapat disimpulkan bahawa semua jenis bahan yang mengandungi al-Quran dalam bahasa Arab sama ada disertakan dengan terjemahan ataupun tidak adalah tertakluk kepada kawalan kerajaan. Kawalan ini bertujuan agar setiap produk yang dihasilkan adalah 'betul'. 'Betul' dalam konteks ini bermaksud 'berkeadaan lengkap dan tersusun dengan betul...' (APTQ, 2008: 5-6).

APTQ juga mengawal kaedah penulisan al-Qur'an dengan tujuan untuk mengelakkan daripada berlakunya perbezaan bacaan yang boleh menyebabkan berbeza makna. Bagi tujuan tersebut, pihak KDN melalui Lembaga Pengawalan dan Pelesenan Pencetakan al-Qur'an (LPPPQ) telah memutuskan supaya penulisan teks 
al-Qur'an mesti berpandukan kepada kaedah Rasm Uthmani. Keputusan ini adalah bertepatan dengan syarat penulisan al-Qur'an yang disepakati oleh sebahagian besar ulama al-Qur'an. Oleh itu satu panduan penulisan al-Quran yang dinamakan sebagai 'Panduan Rasm Uthmani' telah dihasilkan.

Memandangkan AMCP dan APTQ masing-masing digubal pada pada tahun 1984 dan 1986 sedangkan aktiviti terjemahan al-Quran di Malaysia telah bermula lebih awal daripada tarikh tersebut, maka APTQ telah memperuntukkan beberapa kaedah kawalan sepertimana berikut:

a. Perakuan teks al-Qur'an yang dicetak sebelum akta digubal.

Seksyen 12 (1) memperuntukkan syarat kepada penerbit agar mengemukakan teks alQur'an tersebut kepada pihak Lembaga Pengawalan dan Pelesenan Pencetakan alQuran (LPPPQ) untuk tujuan semakan. Pernyataan tersebut adalah sebagaimana berikut:

seseorang yang bermaksud menjual, mengedarkan atau menerbitkan sesuatu teks al-Qur'an yang dicetak sebelum akta ini berkuatkuasa hendaklah mengemukakan teks al-Qur'an itu kepada Lembaga supaya ia diteliti oleh Lembaga dan untuk Lembaga memperakui bahawa ayat-ayat al-Qur'an yang terkandung di dalamnya adalah betul. 2008:12-13)

b. Keperluan penyemakan dilakukan dengan kadar segera

Sekyen 12 (2) mensyaratkan agar semakan dibuat secepat mungkin kerana al-Qur'an tersebut sudah diterbit dan diedarkan tetapi kesahihannya masih belum diperakukan. Pernyataan tersebut adalah berikut:

(2) Dengan seberapa segera yang boleh selepas menerima suatu teks al-Quran di bawah subseksyen (1), lembaga hendaklah meneliti teks al-Quran itu dan memutuskan sama ada ayat-ayat al-Quran yang terkandung di dalamnya adalah betul. (APTQ, 2008:12-13)

c. Keperluan mempamerkan perakuan pada bahagian yang mudah dilihat Keperluan tersebut dinyatakan dalam Sekyen 12 (3) seperti berikut:

(3) Jika Lembaga berpuas hati bahawa ayat-ayat al-Quran yang terkandung di dalam teks al-Quran itu betul, Lembaga hendaklah memperakui sedemikian 
dan hendaklah menyebabkan suatu perakuan yang bermaksud sedemikian ditampalkan dengan ketara pada helai bercetak yang pertama atau yang akhir teks itu atau, dalam hal sesuatu teks rakaman, pada suatu bahagian mudah dilihat teks itu.

d. Keperluan melakukan pembetulan atau pelupusan.

Sekiranya teks al-Qur'an yang sudah dicetak sebelum daripada akta ini berkuat kuasa dan mengandungi kesilapan atau kesalahan, maka pihak Lembaga Pengawalan dan Pelesenan Pencetakan al-Qur'an (LPPPQ) perlu meminta pemohon membuat pembetulan terhadap teks al-Qur'an yang salah. Sekiranya kesalahan tersebut sangat besar sehingga sukar untuk dibuat pembetulan, maka pihak LPPPQ perlu melupuskan teks al-Qur'an tersebut. Peruntukan kuasa untuk peritah pembetulan dan melakukan pelupusan terhadap teks ini dijelaskan dalam APTQ seksyen 12 (4) dan (5).

iii. Akta Pentadbiran Undang-Undang Islam (Wilayah-Wilayah Persekutuan) 1993 (Akta 505)

Akta ini digubal oleh Parlimen bagi tujuan penguatkuasaan dan pentadbiran undangundang Islam, penubuhan dan organisasi Mahkamah-Mahkamah Syariah. Penggubalan akta pentadbiran undang-undang Islam wilayah ini disahkan oleh Seri Paduka Baginda Yang diPertuan Agong (YDPA) kerana ketua bagi hal ehwal agama Islam wilayah persekutuan ialah (YDPA) (Akta Pentadbiran Undang-undang Islam Wilayah-wilayah Persekutuan, 1993: Muqaddimah). Adapun Bahagian III Seksyen 39 (1), (2) dan (3) menyenaraikan panduan mengenai nas-nas yang perlu diikuti dalam berfatwa dan berijtihad untuk para mufti di peringkat Wilayah Persekutuan. Seksyen 39 (1) mensyaratkan agar para mufti mengambil pendapat yang kuat daripada mazhab Shafie dalam mengeluarkan sesuatu fatwa (Akta Pentadbiran Undang-Undang Islam Wilayah-Wilayah Persekutuan, 1993: Bahagian III Seksyen 39 (1)). Seksyen yang sama kurungan dua (2) membenarkan para mufti untuk mengambil pendapat mazhab Hanbali, Maliki atau Hanafi sekiranya pendapat Shafie bertentangan dengan kepentingan awam (Akta Pentadbiran Undang-Undang Islam Wilayah-Wilayah Persekutuan, 1993: Bahagian III Seksyen 39 (2)). Adapun kurungan tiga (3) membenarkan para mufti untuk berijtihad sendiri sekiranya tidak kedapatan pendapat yang sesuai dengan konteks Malaysia di dalam mana-mana mazhab tersebut (Akta Pentadbiran Undang-Undang Islam Wilayah-Wilayah Persekutuan, 1993: Bahagian III Seksyen 39 (3)). 
Dalam konteks terjemahan al-Quran, APTQ 1986 Seksyen 16 telah meletakkan syarat al-Quran yang dicetak dan diedarkan di Malaysia perlu mendapat pengesahan daripada para mufti (APTQ, 2008: 14-15). Oleh yang demikian, Akta 505 turut dirujuk bagi tujuan kawalan al-Quran apabila melibatkan terjemahan lafaz atau ayat al-Quran yang mungkin ditafsir secara berbeza-beza mengikut mazhab. Dalam hal ini, para mufti perlu memastikan bahawa sesuatu terjemahan yang dihasilkan itu adalah selari dengan pandangan mazhab Shafie. Sekiranya tiada pendapat Mazhab Shafie yang sesuai dengan kepentingan masyarakat Malaysia, para mufti boleh mengambil pendapat mazhab Hanbali, Maliki atau Hanafi yang lebih menepati kepentingan awam. Para mufti juga boleh berijtihad sendiri sekiranya tiada pendapat yang sesuai dengan konteks Malaysia dalam mana-mana mazhab tersebut.

\section{Enakmen dan Ordinan}

Enakmen ialah undang-undang yang dibuat di peringkat negeri, manakala di negeri Sarawak enakmen dikenali sebagai ordinan. Semua negeri di Malaysia mengawal institusi fatwa dengan menggubal satu enakmen pentadbiran Islam sebagai garis panduan kepada para mufti dan jawatan kuasa fatwa dalam membuat sebarang fatwa. Semua negeri, kecuali Perlis (Enakmen Pentadbiran Agama Islam (Negeri Perlis), 2006: Seksyen 54 (1)) sepakat menjadikan mazhab Shafie sebagai mazhab utama yang perlu diikuti dalam berfatwa bagi permasalahan dalam bidang fekah . Para mufti dan jawatan kuasa fatwa juga diberi ruang untuk memilih mazhab Hanbali, Maliki atau Hanafi sekiranya pendapat-pendapat tersebut tidak terdapat dalam mazhab Shafie. Sekiranya tiada pendapat dalam mana-mana mazhab yang empat tersebut, maka para mufti dan jawatan kuasa fatwa dibenarkan untuk mengeluarkan pendapat sendiri. Garis panduan ini dinyatakan dalam Enakmen 10, Enakmen Mufti Dan Fatwa (Kedah Darul Aman) 2008, Enakmen 16, Enakmen Pentadbiran Agama Islam (Negeri Johor) 2003, Enakmen 7, Enakmen Pentadbiran Agama Islam (Negeri Melaka) 2002,Enakmen 1, Enakmen Pentadbiran Agama Islam (Negeri Selangor) 2003, Enakmen 10, Enakmen Pentadbiran Agama Islam (Negeri Sembilan) 2003, Enakmen 2, Enakmen Pentadbiran Agama Islam (Negeri Pulau Pinang) 2004, Enakmen 4, Enakmen Pentadbiran Agama Islam (Perak) 2004, Enakmen 2, Enakmen Pentadbiran Hal Ehwal Agama Islam (Terengganu) 2001, Enakmen 3, Enakmen Pentadbiran Undang-Undang Islam (Pahang) 1991, Enakmen 7, Enakmen Fatwa (Sabah) 2004, Ordinan 41, Ordinan Majlis Islam Sarawak, 2001. Adapun Enakmen Majlis Agama Islam dan Adat Istiadat Melayu Kelantan 1994 pula menambah keperluan mengikut pendapat ahli sunah waljamaah sekiranya sesuatu fatwa tersebut berkaitan dengan bidang akidah. 
Dalam konteks terjemahan al-Qur'an, enakmen-enakmen tersebut turut mengawal proses terjemahan al-Qur'an agar selari dengan tafsiran dan pendapat mazhab Shafie dan mazhab yang muktabar dalam bidang fekah serta menepati pegangan aliran ahli sunah waljamaah dalam bidang akidah. Hal ini demikian bermakna mana-mana terjemahan al-Qur'an yang bercanggah dengan mazhab dan akidah tersebut boleh dihalang daripada diterbit dan disebarkan di mana-mana negeri di Malaysia.

\section{Garis Panduan}

Garis Panduan bermaksud dokumen perincian terhadap pernyataan-pernyataan umum yang terdapat dalam akta. Tujuan perincian ini dibuat adalah supaya pernyataan-pernyataan umum yang terkandung dalam akta dapat diperjelas supaya dapat difahami dengan mudah dan proses kawalan dapat dilakukan secara tersusun.

Dalam konteks kawalan terjemahan al-Quran, beberapa garis panduan telah dikenal pasti, iaitu a) Garis Panduan Penerbitan, b) Garis Panduan Peraturan Yang Berkaitan Akta Percetakan Teks al-Quran 1986 (Akta 326), c) Panduan Rasm Uthmani dan d) Garis panduan JAKIM mengenai Rujukan Dalam Bidang Akidah Islam.

i) Garis panduan penerbitan

Garis panduan penerbitan ialah penjelasan kepada tujuh (7) hasil penerbitan tak diingini yang digariskan di bawah seksyen 7(1) Akta Mesin Cetak dan Penerbitan 1984. Terdapat tujuh (7) perkara yang dianggap sebagai perkara yang tak diingini iaitu:

a. memudaratkan ketenteraman awam

b. memudaratkan keselamatan

c. memudaratkan kemoralan

d. menggemparkan fikiran orang ramai

e. berlawanan dengan mana-mana undang-undang

f. memudaratkan kepentingan awam

g. memudaratkan kepentingan negara

Berkaitan dengan terjemahan al-Quran, mana-mana terjemahan al-Quran yang salah dan bertentangan dengan aliran ahli sunah waljamaah adalah 
dianggap sebagai 'Perkara Yang Tak Diingini' kerana mengandungi unsur-unsur yang memudaratkan masyarakat. Justeru, terjemahan al-Quran juga tertakluk di bawah 'Garis Panduan Penerbitan'.

ii) Garis Panduan Peraturan Yang Berkaitan Akta Percetakan Teks al-Quran 1986 (Akta 326)

Garis panduan ini diterbitkan dengan tujuan untuk mengawal aktiviti penghasilan, pengendalian, penjualan dan pelupusan teks al-Quran, dan bahan yang mengandungi ayat-ayat suci al-Quran. Antara kandungan garis panduan ini ialah mensyaratkan agar penulisan teks al-Quran perlu mengguna pakai kaedah rasm uthmani (Garis Panduan Peraturan Yang Berkaitan Akta Percetakan Teks al-Quran 1986: 6 \& 19).

Berkaitan dengan terjemahan al-Quran, garis panduan ini mensyaratkan agar bahan penerbitan yang mengandungi teks al-Quran dan terjemahannya perlu melalui proses semakan oleh pakar dalam bidang al-Quran. Para penerbit juga perlu mengikut prosedur penerbitan seperti memohon lesen dan beberapa peraturan yang telah digariskan dalam garis panduan ini (Garis Panduan Peraturan Yang Berkaitan Akta Percetakan Teks al-Quran 1986: 8).

\section{iii) Panduan Rasm Uthmani}

Dokumen ini adalah merupakan salah satu garis panduan berkenaan dengan kaedah penulisan al-Quran. Kaedah Rasm Uthmani merujuk kepada cara penulisan al-Quran yang ditetapkan pada zaman pemerintahan Khalifah Uthman bin Affan. Kaedah ini dibuat berpandukan kepada bacaan para Qurra’ iaitu pakar al-Quran dalam kalangan Sahabat dan kaedah penulisan orang-orang Quraisy (Panduan Rasm Uthmani, 2012: 18).

Kaedah ini juga mempunyai beberapa keistimewaan, antaranya ialah:

a. Mengikut sunnah Rasulullah s.a.w.

b. Boleh memahami makna yang berlainan dan tidak terkeluar dari maksud yang sebenar.

c. Memudahkan bacaan walaupun pelbagai jenis qiraat (bentuk bacaan).

d. Dipersetujui oleh lebih dari 12,000 orang sahabat.

e. Bertepatan dengan riwayat bacaan mutawatir.

f. Digubal berdasarkan dalil-dalil yang kuat dan hujjah yang jelas.

g. Ditulis mengikut bacaan rawi (periwayat). 
h. Mengandungi maksud-maksud tertentu daripada segi pengekalan dan pengguguran huruf (Panduan Rasm Uthmani, 2012: 19-20).

Walaupun terdapat beberapa kaedah untuk menulis al-Quran, tetapi sebahagian besar ulama salaf (terdahulu) dan khalaf (terkemudian) berpendapat wajib menulis al-Quran dengan kaedah ini (al-Hasan M. Ali 1983: 95-96; Abd. Rahman Abd Ghani 2008: 79-82). Pendapat ini turut diguna pakai oleh kerajaan Malaysia sebagai kaedah yang perlu dipatuhi oleh para penerbit dan pencetak al-Quran (Garis Panduan Peraturan Yang Berkaitan Akta Percetakan Teks Al-Quran 1986: 6 \& 19). Secara umumnya panduan ini menyentuh kawalan terhadap penulisan teks al-Quran dan tidak menyentuh mengenai terjemahan. Namun begitu, disebabkan oleh fatwa di Malaysia telah mensyaratkan agar penulisan terjemahan makna al-Quran perlu disertai dengan teks al-Quran maka aktiviti dan proses terjemahan turut dikawal secara bersama dengan teks al-Quran.

iv) Garis panduan JAKIM mengenai Asas Rujukan Dalam Bidang Akidah Islam

Garis Panduan ini diwujudkan sebagai asas dan rujukan kepada para pegawai Jabatan Kemajuan Islam Malaysia (JAKIM) dan Jabatan Agama negeri dalam menangani permasalahan akidah dan isu yang berkaitan. Garis panduan ini juga bertujuan untuk mengelak daripada berlakunya perselisihan pendapat mengenai persoalan akidah dalam masyarakat khususnya yang bertentangan dengan fahaman ahli sunah waljamaah. Fahaman ahli sunah waljamaah ditakrifkan dalam garis panduan ini sebagai "orang yang terdahulu dari kalangan umat Islam iaitu para sahabat dan tabi in yang sepakat di atas al-Haq yang amat jelas iaitu menerima Al-Quran dan Al-Sunnah” (Abdul Hamid @ Yusuff bin Yunus, 2010: 4).

Dokumen ini menggariskan tujuh asas umum pegangan ahli sunnah wal jamaah sebagaimana berikut:

a. Mengutamakan al-Quran dan al-Sunnah.

b. Mentafsirkan al-Quran dengan al-Quran.

c. Mentafsirkan al-Quran dengan al-Sunnah.

d. Mengutamakan pendapat Sahabat dan Tabi in.

e. Meraikan kaedah-kaedah Bahasa Arab dalam memahami nas.

f. Berpegang kepada zahir nas kecuali ada bukti ia tidak dikehendaki. 
g. Mengutamakan tanzih (mensucikan Allah daripada menyerupai makhluk dan dari mana-mana sifat kekurangan, bahawa hakikat ketuhanan itu tidak terjangkau akal atau transcendence, hampir sama maksud dengan mukhalafatuhu lil hawadith) dan taqdis (penyucian Allah) dalam persoalan mutasyabihat (ayat-ayat yang mengandungi perkataan yang sama dengan makhluk) (Abdul Hamid @ Yusuff bin Yunus, 2010: 4).

Dokumen ini turut menyatakan bahawa hanya aqidah dan fahaman Ahli Sunnah Wal Jamaah sahaja yang dijadikan pegangan dan amalan rasmi kerajaan Malaysia dan rakyatnya serta tidak menerima fahaman selainnya (Abdul Hamid @ Yusuff bin Yunus, 2010: 3).

Dalam konteks tafsiran dan terjemahan al-Quran pula, garis panduan ini perlu dipatuhi dalam proses dan tatacara mentafsir makna al-Quran serta menterjemahkannya ke dalam bahasa Melayu. Tatacara ini perlu diikuti bagi memastikan terjemahan ayat-ayat al-Quran khususnya daripada jenis mutasyabihat (ayat-ayat yang mengandungi sifat yang sama dengan makhluk) dibuat berdasarkan fahaman ahli sunah waljamaah.

\section{Fatwa}

Fatwa ialah "keputusan tentang sesuatu hukum agama (yang belum pernah diputuskan lagi) berdasarkan nas al-Quran, hadis dan sumber hukum lain termasuk ijtihad oleh mufti atau mereka yang berwenang tentang keputusan hukum syarak" (Kamus Dewan 2010: 408).

Amalan di Malaysia, fatwa dikeluarkan oleh mufti atau jawatankuasa fatwa. Dalam proses mengeluarkan fatwa, beberapa orang pakar dalam bidang berkaitan diberi ruang untuk membantu mufti dan jawatankuasa fatwa membuat keputusan mengenai hukum syarak.

Berdasarkan pemerhatian, terdapat dua jenis fatwa di Malaysia iaitu fatwa pada peringkat tempatan dan fatwa pada peringkat nasional. Fatwa peringkat tempatan dinamakan sebagai fatwa negeri dan fatwa peringkat nasional dinamakan fatwa kebangsaan atau keputusan muzakarah Jawatankuasa Fatwa Majlis Kebangsaan bagi Hal Ehwal Ugama Islam Malaysia (JFMKI). Fatwa negeri hanya boleh diguna pakai di peringkat negeri sahaja, manakala fatwa JFMKI adalah fatwa yang dirujuk oleh negeri-negeri di peringkat kebangsaan. Fatwa yang diputuskan melalui Muzakarah JFMKI boleh dipinda oleh negeri. Akan tetapi, fatwa yang diputuskan melalui Mesyuarat JFMKI tidak boleh dipinda sewenang-wenangnya oleh negerinegeri tanpa kebenaran rasmi daripada Majlis Raja-raja (Hasnan Kasan 2001: 42). 
Sesuatu fatwa yang telah diwarta akan menjadi undang-undang yang wajib dipatuhi oleh semua pihak.

Berkaitan dengan terjemahan al-Quran, terdapat beberapa fatwa yang perlu diambil kira bagi melakukan aktiviti penterjemahan al-Quran, antaranya ialah:

a. Fatwa negeri Kedah yang dikeluarkan pada 27 Jan, 2001 menyatakan bahawa Penulisan al-Quran dan terjemahannya perlu digandingkan bersama secara bersebelahan di dalam satu dokumen (Tafsir al-Quran, 2015). Dengan kata lain, terjemahan al-Quran perlu disertakan dengan teks asal alQuran dalam bahasa Arab. Walaupun fatwa ini hanya diperingkat negeri dan tidak diwartakan tetapi syarat ini dilihat diguna pakai oleh pihak KDN. Hal ini dapat diperhatikan melalui beberapa penerbitan terjemahan alQuran yang telah diharamkan oleh KDN kerana tidak disertakan dengan teks asal al-Quran. Sebagai contoh, hasil terjemahan tanpa teks asal berjudul 'Bacaan' terbitan Singapura dan 'Terjemahan al-Quran bahasa Melayu' terbitan al-Madinah, Kuala Lumpur.

b. Keputusan Muzakarah JFMKI kali ke-8 yang telah diadakan pada 24 dan 25 September 1984 telah menetapkan bahawa umat Islam di Malaysia hendaklah hanya mengikut ajaran Islam yang berasaskan pegangan ahli sunah waljamaah dari segi akidah, syariah dan akhlak (Mohd Aizam Bin Masod, 2015: 14).

c. Keputusan Muzakarah Khas JFMKI yang bersidang pada 5 Mei 1996 telah memutuskan bahawa penerbitan, penyiaran dan penyebaran apa-apa buku, risalah, filem video dan lain-lain berhubung dengan ajaran Islam yang bertentangan dengan pegangan ahli sunah waljamaah adalah diharamkan (Mohd Aizam Bin Masod, 2015: 14-15).

Kesan kedua-dua fatwa JFK ini menyebabkan terjemahan al-Quran perlu dilakukan mengikut aliran ahli sunah waljamaah. Hal ini juga bermaksud terjemahan makna al-Quran yang bertentangan dengan akidah ahli sunah waljamaah adalah dilarang oleh kerajaan Malaysia.

\section{Organisasi Kawalan Aktiviti Terjemahan al-Qur'an}

Organisasi-organisasi yang terlibat dengan kawalan terjemahan al-Quran di Malaysia ialah Kementerian Dalam Negeri (KDN), Jabatan Kemajuan Islam Malaysia (JAKIM), Jawatankuasa Fatwa Majlis Kebangsaan Bagi Hal Ehwal Ugama Islam 
Malaysia dan Pihak Berkuasa Agama Negeri yang terdiri daripada Jabatan Agama Islam negeri dan Jabatan Mufti.

Secara umumnya kawalan al-Quran di Malaysia dipertanggungjawabkan kepada Kementerian Dalam Negeri (KDN). Namun, disebabkan oleh al-Quran dan kandungannya terletak di bawah bidang kuasa Jabatan Kemajuan Islam Malaysia (JAKIM), maka usaha ini dilakukan secara bersepadu bersama JAKIM dengan pusat pengurusan dan pentadbiran ditempatkan di bawah $\mathrm{KDN}$.

Dalam keadaan tertentu, kuasa kawalan diperluaskan kepada pihak berkuasa negeri, iaitu Jabatan Agama Negeri dan Jabatan Mufti. Peruntukan kuasa ini dijelaskan di dalam APTQ Seksyen 4 Peluasan Kuasa Eksekutif Negeri (APTQ, 2008: 8). Ringkasnya agensi-agensi ini akan bekerjasama secara bersepadu dengan kuasa kawalan utama terletak di bawah pengurusan $\mathrm{KDN}$.

\section{Kementerian Dalam Negeri (KDN)}

KDN diwujudkan pada bulan Mac 1951 iaitu semasa 'Sistem Ahli' (Member System) diperkenalkan oleh pemerintah Inggeris di Persekutuan Tanah Melayu. Objektif penubuhan kementerian ini ialah memastikan keselamatan negara dan ketenteraman awam sentiasa terjamin dan terpelihara melalui penguatkuasaan undang-undang dan kecekapan pelaksanaan dasar-dasar kementerian. Fungsi KDN boleh dirumuskan kepada 10 bidang utama dan antaranya ialah kawalan penerbitan dan teks al-Quran (http://www.moha.gov.my/).

Berhubung dengan fungsi kawalan penerbitan dan teks al-Quran, KDN mengawal selia aktiviti tersebut berdasarkan akta dan peraturan-peraturan sedia ada dengan menyusun organisasi kepada 3 unit utama iaitu Lembaga Pengawalan dan Pelesenan Pencetakan al-Quran (LPPPQ), Unit Kawalan al-Quran dan Jawatankuasa Penyemakan dan Penilaian Teks al-Quran atau dikenali sebagai Lajnah Tashih alQuran.

i) Lembaga Pengawalan dan Pelesenan Pencetakan al-Quran (LPPPQ)

LPPPQ ditubuhkan di bawah Akta Pencetakan Teks al-Quran 1986 melalui peruntukkan seksyen 3(1) yang berbunyi:

“3. (1) Bagi maksud akta ini, maka hendaklah ada suatu lembaga yang dikenali sebagai Lembaga Pengawalan dan Pelesenan Pencetakan al-Quran" (APTQ, 2008: 7) 
Ahli-ahli LPPPQ terdiri daripada lima belas (15) orang anggota yang terdiri daripada kalangan para Mufti atau Kadi Besar setiap negeri dan Ketua Pengarah Jabatan Kemajuan Islam Malaysia (JAKIM), Jabatan Perdana Menteri (APTQ, 2008: 7; Panduan Rasm Uthmani, 2012: 108).

LPPPQ diberi hak untuk mengawal selia tatacaranya sendiri, namun keseluruhan aktiviti kawalan dan pengawasan adalah tertakluk kepada arahan dan keputusan menteri (APTQ, 2008: 7).

LPPPQ mempunyai dua fungsi utama iaitu yang pertama ialah mengawal selia dan menguat kuasa aktiviti percetakan dan pengedaran bahan-bahan penerbitan. Adapun fungsi kedua ialah memastikan kesahihan dan mencegah penyelewengan teks dan bahan al-Quran.

Bagi usaha pengawalan, pihak LPPPQ menjalankan tujuh aktiviti berikut:

a. Menerima, menimbang dan membatalkan lesen mencetak/menerbit teks al-Quran

b. Menerima, menimbang dan memperakui kesahihan pruf akhir teks alQuran sebelum dicetak atau diterbit.

c. Menerima, menimbang dan memperakui permohonan mengimport teks al-Quran dari luar negara

d. Meneliti dan memperakui kesahihan teks al-Quran yang dikemukakan untuk tujuan jualan, edaran atau terbitan di dalam negara.

e. Memastikan kaedah penggunaan rasm (penulisan) dan dhabt (penandaan) serta penentuan ayat al-Quran yang betul.

f. Penyelarasan Rasm al-Quran (kaedah penulisan al-Quran) di Malaysia khususnya penggunaan rasm uthmani.

g. Melakukan Pelupusan Bahan Teks Al-Quran (Panduan Rasm Uthmani 2012: $108 \& 111-112$ )

Dalam konteks terjemahan al-Quran, LPPPQ bertanggungjawab memastikan semua bahan penerbitan dan teks Al-Quran yang dicetak, diterbit, diimport dan diedar di Malaysia tidak mengandungi kesilapan dan tidak mengandungi bahan-bahan yang bercanggah dengan Islam dan dasar negara. Bahanbahan sebegini perlu dikawal kerana boleh menjejaskan kemuliaan al-Qur'an dan memudaratkan keselamatan negara, ketenteraman awam serta kesejahteraan rakyat. 


\section{ii) Unit Kawalan al-Quran, KDN}

Unit Kawalan al-Quran Kementerian Dalam Negeri ditubuhkan pada 1987. Pada awalnya unit ini dikenali sebagai Urusetia LPPPQ KDN. Urusetia ini kemudiannya dinamakan sebagai Unit Kawalan al-Quran, KDN. Fungsi unit ini ialah membantu LPPPQ dalam hal ehwal pentadbiran dan pengurusan berdasarkan peruntukan undang-undang yang sedia ada (Panduan Rasm Uthmani, 2012: 110).

iii) Jawatankuasa Penyemakan dan Penilaian Teks al-Quran (Lajnah Tashih alQuran)

Keanggotaan jawatankuasa ini pada awal penubuhannya ialah seramai 7 orang pakar yang terdiri daripada penghafal al-Quran, kemudian keahliannya ditambah seramai 8 orang menjadikan jumlah keseluruhannya seramai 15 orang. Pada tahun 1995, keahlian telah ditambah lagi seramai 15 orang menjadikan ahli lajnah seramai 30 orang. Setelah bebanan tugasan semakin meningkat, maka 5 orang ahli lagi ditambah menjadikan jumlah keseluruhan 35 orang dan kekal sehingga sekarang (Panduan Rasm Uthmani 2012: 113 \& 115).

Tanggungjawab jawatankuasa ini ialah menyemak dan menilai teks dan bahan al-Quran. Perincian bidang kuasa lajnah iai adalah seperti berikut:

a. Menyemak semua teks atau bahan al-Quran yang dikemukakan oleh urusetia.

b. Menyediakan laporan penyemakan secara bersistematik.

c. Membuat resolusi penyemakan.

d. Melapor keputusan dan penyemakan.

e. Membuat pendedahan mengenai Rasm Uthmani kepada masyarakat awam.

f. Menyediakan kertas kerja yang berkaitan dengan penyelarasan pengawalan teks al-Quran.

g. Membuat kajian dan mencadangkan kaedah penyemakan teks alQuran yang efisyen dan sistematik dalam meningkatkan kualiti penyemakan teks al-Quran di Malaysia.

h. Menerima dan memberi maklumbalas berhubung dengan aduan orang ramai mengenai al-Quran. (Panduan Rasm Uthmani 2012: 109) 
II. Jabatan Kemajuan Islam Malaysia (JAKIM), Jabatan Perdana Menteri (JPM).

Keterlibatan JAKIM dalam aktiviti kawalan terhadap percetakan al-Quran adalah berdasarkan kepada penentuan ahli LPPPQ yang dinyatakan dalam Seksyen 3 (2) APTQ iaitu:

Lembaga hendaklah terdiri daripada lima belas orang anggota...dan seorang ialah Ketua Pengarah Jabatan Kemajuan Islam Malaysia, Jabatan Perdana Menteri. (Akta percetakan Teks al-Qur'an 1986, 2008: 7)

Keperluan Ketua Pengarah JAKIM sebagai salah seorang anggota LPPPQ menyebabkan JAKIM turut terlibat secara bersepadu dalam hal-hal berkaitan dengan kawalan dan penguatkuasaan.

Penubuhan JAKIM adalah berasaskan kepada Perlembagaan Persekutuan dalam perkara 3 (1) yang menyatakan bahawa "Islam adalah agama bagi Persekutuan. Penubuhannya telah dipersetujui oleh Majlis Raja-Raja pada tahun 1968 dengan nama asalnya ialah Majlis Kebangsaan Bagi Hal Ehwal Agama Islam Malaysia (MKI). Pada tahun 1974, MKI telah dinaikkan tarafnya kepada sebuah Bahagian Agama di Jabatan Perdana Menteri dan diberi nama Bahagian Hal Ehwal Islam (BAHEIS). Pada 2 Oktober 1996, Mesyuarat Jemaah Menteri telah bersetuju supaya BAHEIS, Jabatan Perdana Menteri dinaikkan taraf menjadi sebuah Jabatan pada 1 Januari 1997 dengan nama Jabatan Kemajuan Islam Malaysia (JAKIM). Penubuhan JAKIM telah menjadi salah satu landasan di dalam memenuhi keperluan masyarakat Islam seiring dengan perkembangan dan pembangunan negara yang menjadikan Islam sebagai agama rasmi. Matlamat utama penubuhan JAKIM ialah membina ummah yang bertamadun melalui ajaran Islam kepada seluruh masyarakat di Malaysia (Sejarah Jakim, 2005).

Berkaitan dengan aktiviti pengawalan al-Quran, JAKIM bekerjasama secara bersepadu dengan KDN (Panduan Rasm Uthmani, 2012: 114). Bahagian yang bertanggungjawab secara langsung terhadap aktiviti berkaitan al-Quran di JAKIM ialah Pusat Penyelidikan Islam. Pusat Penyelidikan ini ditubuhkan pada tahun 1971 dengan objektif mengkaji dan menyelidik masalah semasa yang dihadapi oleh masyarakat Islam dan memberi pandangan serta perakuan bagi mengatasi pelbagai masalah termasuk penterjemahan al-Quran di Malaysia. Penglibatan JAKIM dengan aktiviti terjemahan al-Quran bermula sejak awal penubuhan JAKIM iaitu semasa dikenali sebagai MKI lagi. Pada masa tersebut YTM Tunku Abdul Rahman Putra AlHaj telah mengarah urus setia MKI supaya menerbitkan sebuah kitab tafsir al-Quran dalam bahasa Melayu. Usaha yang dimulakan pada tahun 1968 ini hanya berjalan 
secara sistematik apabila Unit Dokumentasi diwujudkan di Cawangan Pusat Penyelidikan Islam pada tahun 1974 (Wan Ramizah 2000: 210-213).

\section{Pihak Berkuasa Agama Negeri}

Penglibatan pihak berkuasa agama negeri dalam aktiviti kawalan al-Qur'an disebut dalam Seksyen 4 Peluasan Kuasa Eksekutif Negeri, APTQ 1986 sebagaimana berikut:

\section{Peluasan Kuasa Eksekutif Negeri}

4. Bagi mengelakkan keraguan adalah dengan ini diistiharkan:

a) bahawa jika ternyata, secara langsung atau implikasi, bahawa kuasa eksekutif sesuatu negeri diperluaskan kepada pentadbiran mana-mana peruntukan akta ini, peluasan itu adalah diperuntukkan menurut kuasa Fasal (4) Perkara 80 Perlembagaan Persekutuan; (APTQ, 2008: 8)

Merujuk kepada pernyataan tersebut, dalam konteks kawalan al-Qur'an dan terjemahannya, kerjasama KDN dan JAKIM boleh diperluaskan kepada Jabatan Agama Islam Negeri (JAIN) dan Jabatan Mufti negeri. Hal ini adalah bersesuaian dengan tanggungjawab JAIN dalam hal ehwal Islam peringkat negeri khususnya dalam menjaga akidah dan syariat masyarakat dengan cara pemantauan dan penguatkuasaan. JAIN juga bertanggungjawab mengawasi pengajaran dan amalan yang bertentangan dengan ajaran Islam. Rentetan daripada itu, JAIN bekerjasama dengan organisasi daripada kerajaan pusat seperti KDN dan JAKIM dalam penguatkuasaan peraturan penulisan dan penterjemahan al-Quran. Adapun Jabatan Mufti di setiap negeri pula berfungsi sebagai penasihat kepada Sultan, Kerajaan Negeri dan masyarakat negeri masing-masing dalam hal yang berkaitan dengan hukum-hakam Islam dan persoalan semasa umat Islam melalui fatwa. Dalam konteks terjemahan al-Quran, Jabatan Mufti bertanggungjawab mengeluarkan fatwa-fatwa berkaitan dengan al-Quran dan terjemahannya agar penerbit dan penterjemah alQuran sentiasa memastikan bahawa hasil kerja mereka adalah selari dengan pandangan mazhab Shafie, Hanbali, Maliki dan Hanafi serta menepati fahaman ahli sunah waljamaah.

IV. Jawatankuasa Fatwa Majlis Kebangsaan Bagi Hal Ehwal Islam (JFMKI) Jawatankuasa Fatwa Majlis Kebangsaan Bagi Hal Ehwal Ugama Islam Malaysia (JFMKI) ditubuhkan pada awal tahun 1970 di bawah peruntukan Perkara 11 
Peraturan Majlis Kebangsaan Bagi Hal Ehwal Ugama Islam Malaysia (MKI). Jawatankuasa ini berfungsi sebagai badan pengeluar fatwa paling berautoriti pada peringkat Kebangsaan. Aktiviti mengeluarkan sesuatu fatwa oleh JFMKI dinamakan sebagai 'persidangan' dan 'muzakarah'. Tugas JFMKI ditentukan oleh Perkara 14 Peraturan MKI iaitu menimbang, memutus dan mengeluarkan fatwa berkenaan dengan agama Islam yang dirujuk oleh Majlis Raja-Raja. JFMKI akan mengemukakan pendapat-pendapatnya kepada MKI yang kemudian akan dihantar bersama dengan cadangan-cadangan kepada Majlis Raja-Raja (Muhammad Ikhlas Rosele, Luqman Hj Abdullah, Paizah Hj Ismail \& Mohd Anuar Ramli, 2013: 3334).

Keanggotaan JFMKI terdiri daripada sembilan orang alim ulama atau mufti bagi tiap-tiap negeri yang mengambil bahagian atau seorang yang mewakili negeri dalam hal ehwal agama Islam, para pakar muslim dan seorang ahli yang beragama Islam daripada Perkhidmatan Kehakiman dan Undang-undang atau daripada profession undang-undang yang dipilih dan dilantik oleh Majlis Raja-Raja (Jawatankuasa Fatwa Majlis Kebangsaan Bagi Hal Ehwal Ugama Islam Malaysia, 2016; Mohamad bin Saari, 2012: 57).

Pengeluaran pandangan hukum atau fatwa oleh JFMKI adalah melalui dua cara iaitu cara yang pertama ialah melalui Mesyuarat JFMKI dan cara kedua ialah melalui Muzakarah JFMKI. Mesyuarat JFMKI diadakan apabila dititahkan oleh Mesyuarat Majlis Raja-Raja. Manakala Muzakarah JFMKI pula diadakan apabila terdapat permohonan dari masyarakat Islam atau pihak-pihak tertentu (Jawatankuasa Fatwa Majlis Kebangsaan Bagi Hal Ehwal Ugama Islam Malaysia, 2016; Zaini Nasohah, 2005: 33).

Berkaitan dengan aktiviti terjemahan al-Quran, JFMKI dirujuk bagi memastikan terjemahan makna al-Qur'an yang dilakukan oleh sesuatu pihak mesti bertepatan dengan pegangan ahli sunah waljamaah. Sekiranya wujud terjemahan alQuran yang bercanggah dengan pegangan tersebut maka KDN boleh bertindak menghalangnya daripada tersebar di Malaysia.

\section{KESIMPULAN}

Malaysia sebagai sebuah negara yang mengiktiraf Islam sebagai sebuah agama rasmi mempunyai mekanisme yang baik dan tersusun dalam memelihara kesucian Islam. Hal ini turut terbukti melalui kawalan kerajaan terhadap percetakan dan penyebaran al-Quran serta bahan-bahan al-Quran. Kawalan dilakukan secara sah melalui penggubalan dua akta iaitu AMCP dan APTQ. Selain daripada dua akta ini, dokumen perincian akta yang disebut sebagai 'garis panduan' turut diterbitkan agar 
boleh dijadikan rujukan dalam aktiviti penguatkuasaan. Garis panduan tersebut ialah Garis Panduan Penerbitan, Garis Panduan Peraturan Yang Berkaitan Akta Percetakan Teks al-Quran 1986 (Akta 326), Panduan Rasm Uthmani dan Garis panduan JAKIM Mengenai Rujukan Dalam Bidang Aqidah Islam.

Semua dokumen perundangan ini dirujuk dan ditafsirkan secara kolektif bersama dengan fatwa-fatwa diperingkat kebangsaan dan negeri. Tafsiran dokumen secara kolektif ini penting dalam memastikan keabsahan undang-undang kawalan terjemahan makna al-Quran.

Aktiviti kawalan pula dilaksanakan secara bersepadu oleh Kementerian Dalam Negeri (KDN) dan Jabatan Perdana Menteri (JPM) dengan tanggungjawab pentadbiran diuruskan oleh KDN. KDN diwakili oleh tiga unit yang bergabung iaitu Lembaga Pengawalan dan Pelesenan Pencetakan al-Quran, Unit Kawalan al-Quran, dan Jawatankuasa Penyemakan dan Penilaian Teks al-Quran atau dikenali sebagai Lajnah Tashih al-Quran. Adapun JPM pula di wakili oleh JAKIM. Kedua-dua organisasi ini juga perlu bekerjasama dengan kerajaan negeri yang diwakili oleh Jabatan Agama Islam negeri dan Jabatan Mufti. Kerjasama antara kementerian di bawah pentadbiran kerajaan pusat dan kerajaan negeri amat penting untuk memastikan kawalan yang berkesan serta kesucian al-Quran dan agama Islam terus terpelihara.

\section{PENGHARGAAN}

Artikel ini merupakan sebahagian daripada hasil penyelidikan yang dijalankan di bawah pembiayaan Geran Penyelidikan FRGS, Kementerian Pendidikan Malaysia dan Universiti Sains Malaysia [No. Geran: 203/PHUMANITI/6711285].

\subsection{RUJUKAN}

al-Hasan, M.A. (1983). Al-Manar fi 'Ulum al-Qur'an ma ${ }^{c}$ Madkhal fi Usul alTafsir wa-Masadirih. Amman: Matba'ah al-Sharq wa-Maktabatuha.

Akta Mesin Cetak Dan Penerbitan 1984 (Akta 301) \& Kaedah-Kaedah, Bahagian Kawalan Penerbitan \& Teks Al-Quran. (2003). Kuala lumpur: Kementerian Dalam Negeri, Lembaga Penyelidikan Undang-Undang.

Akta Pencetakan Teks al-Quran 1986 (Akta 326). (2008). Kuala Lumpur: Pesuruhjaya Penyemak Undang-undang Malaysia.

Akta Pentadbiran Undang-Undang Islam (Wilayah-Wilayah Persekutuan) 1993. (2002). Dalam Esyariah. Dicapai pada 21 Julai 2016, daripada 
http://www2.esyariah.gov.my/esyariah/mal/portalv1/enakmen/Federal_Update d.nsf/b3ac9c218c8efdc4482568310022d8b3/938ea6c8aaeafd78482571fe0011 dedd?OpenDocument

Garis Panduan Penerbitan. (20 Julai 2016). Kementerian Dalam Negeri. Dicapai pada 26 Julai 2016, daripada http://www.moha.gov.my/index.php/ms/garispanduan-penerbitan-kdn

Kamus Dewan. (2010). Kuala Lumpur : Dewan Bahasa dan Pustaka.

Panduan Rasm Uthmani. (2012). Putrajaya: Lembaga Pengawalan dan Pelesenan Pencetakan al-Quran Kementerian Dalam Negeri..

Enakmen 3, 1991 Enakmen Pentadbiran Undang-Undang Islam (Pahang). (19

Disember 1991). Dalam Esyariah. Dicapai pada 21 Julai 2016, daripada http://www.esyariah.gov.my/

Enakmen 4, 1994 Enakmen Majlis Agama Islam dan Adat Istiadat Melayu Kelantan.

(12 Mei 1994). Dalam Esyariah. Dicapai pada 21 Julai 2016, daripada http://www.esyariah.gov.my/

Enakmen 2, 2001 Enakmen Pentadbiran Hal Ehwal Agama Islam (Terengganu). (22 November 2001). Dalam Esyariah. Dicapai pada 21 Julai 2016, daripada http://www.esyariah.gov.my/

Enakmen 7, 2002 Enakmen Pentadbiran Agama Islam (Negeri Melaka). (28 November 2002). Dalam Esyariah. Dicapai pada 21 Julai 2016, daripada http://www.esyariah.gov.my/

Enakmen 1, 2003 Enakmen Pentadbiran Agama Islam (Negeri Selangor). (24 Julai 2003). Dalam Esyariah. Dicapai pada 21 Julai 2016, daripada http://www.esyariah.gov.my/

Enakmen 16, 2003 Enakmen Pentadbiran Agama Islam (Negeri Johor). (25 Disember 2003). Dalam Esyariah. Dicapai pada 21 Julai 2016, daripada http://www.esyariah.gov.my/

Enakmen 10, 2003 Enakmen Pentadbiran Agama Islam (Negeri Sembilan). (1 Mac 2004). Dalam Esyariah. Dicapai pada 21 Julai 2016, daripada http://www.esyariah.gov.my/

Enakmen 2, 2004 Enakmen Pentadbiran Agama Islam (Negeri Pulau Pinang). (24 November 2005). Dalam Esyariah. Dicapai pada 21 Julai 2016, daripada http://www.esyariah.gov.my/

Enakmen 4, 2004 Enakmen Pentadbiran Agama Islam (Perak). (22 September 2004). Dalam Esyariah. Dicapai pada 21 Julai 2016, daripada http://www.esyariah.gov.my/

Enakmen 7, 2004 Enakmen Fatwa (Sabah). (14 Oktober 2004). Dalam Esyariah. Dicapai pada 21 Julai 2016, daripada http://www.esyariah.gov.my/ 
Enakmen 10, 2008 Enakmen Mufti Dan Fatwa (Kedah Darul Aman). (27 Mac 2008). Dalam Esyariah. Dicapai pada 21 Julai 2016, daripada http://www.esyariah.gov.my/

Ordinan 41, 2001 Ordinan Majlis Islam Sarawak. (27 Disember 2001). Dalam Esyariah. Dicapai pada 21 Julai 2016, daripada http://www.esyariah.gov.my/

Abd. Rahman Abd Ghani. (2008). Rasm Uthmani Pelengkap Pembacaan al-Quran, Kuala Lumpur: Yadim.

Abdul Hamid @ Yusuff bin Yunus. (2010). Asas Rujukan Dalam Bidang Aqidah Islam. Putrajaya: Bahagian Perancangan Dan Penyelidikan, Jabatan Kemajuan Islam Malaysia.

Abdul Raof, M.A. (t.t). Tarikh al-Tarjamah al-Arabiyyah Bain al-Sharq al-Arabiyy Wa al-Gharb al-Urubbiy. Kaherah: Maktabah al-Adab.

Ali, M. M. (2004). The Qur'an and the Orientalists. Ipswich: Jamciyat 'Ihyaa' Minhaaj al-Sunnah.

Atabik Luthfi. (2004). Penterjemahan Dan Pentafsiran Al-Quran Di Indonesia: Kajian Terhadap Perkembangan Metodologi Dan Penyelewengan Pentafsiran. (Tesis Phd). Universiti Kebangsaan Malaysia, Bangi, Malaysia.

Azani Ismail @ Yaakub, Muhammad Fauzi Bin Jumingan, Zulkifli Bin Ismail \& Azman Bin Che Mat. (2014). Satu Pemerhatian Ke Atas Penterjemahan Leksikal Dan Derivasinya Dalam Surah Yusuf. Dalam Redzaudin Ghazali, Shahrul Ridzuan Arshad \& CW Shamsul Bahri CW Ahmad (Ed.) Proceeding of the International Conference on Arabic Studies and Islamic Civilization (hlm: 542-549). Kajang, Malaysia: Kolej Universiti Islam Antarabangsa Selangor.

Hasnan Kasan. (2001). Institusi Fatwa Dalam Perundangan Negara: Satu Penilaian

Menurut Siasah Syar'iyyah. Jurnal Pengajian Umum, 2, 37-63.

Jawatankuasa Fatwa Majlis Kebangsaan Bagi Hal Ehwal Ugama Islam Malaysia.

(2016). Dalam E-Fatwa. Dicapai pada 16 Februari 2016, daripada http://www.e-fatwa.gov.my/jawatankuasa-fatwa-majlis-kebangsaan-bagi-halehwal-ugama-islam-malaysia) dicapai pada 16 Februari 2016

Lefevere, A. (1992). Translation, Rewriting and the Manipulation of Literary Fame. London: Routledge.

Mohamad bin Saari. (2012). Jakim Empat Dekad. Putrajaya: Jabatan Kemajuan Islam Malaysia.

Mohd Aizam Masod. (2015). Diskusi Isu Aqidah Dan Pemikiran Semasa Di Malaysia. Putrajaya. Jabatan Kemajuan Islam Malaysia.

Mohd Fauzi Haji Awang. (1964). Tafsir al-Quran al-Karim Juzu’ Amma. Kelantan: Pustaka Aman Press.

Mohd Hasbie al-Shiddieque Ahmad \& Khairul Anuar Mohamad. (2015). Errors in Printing of Al-Qur'an in Malaysia. Al-Qanatir International Journal of Islamic Studies. 1(1), 1-9. 
Mohd Shukri Hanapi. (2003). Terjemahan al-Quran Dalam Pelbagai Perspektif. Kuala Lumpur: Utusan Publications.

Muhammad Ikhlas Rosele, Luqman Hj Abdullah, Paizah Hj Ismail \& Mohd Anuar Ramli. (2013). Konflik Fatwa Di Malaysia: Satu Kajian Awal. Jurnal Fiqh. 10, $31-56$.

Muhammad Khalifa (1989). The Sublime Qur'an and Orientalism. Karachi: International Islamic Publishers.

Muhammad Mohar Ali. (2004). The Qur'an and the Orientalists. Ipswich: Jamiiyat 'Ihyaa' Minhaaj al-Sunnah.

Muhammad Uthman El-Muhammady. (1992). Al-Quran al-Karim Terjemahan dan Huraian Maksud. Kuala Lumpur. Dewan Bahasa dan Pustaka.

Munday, J. (2012). Introducing Translation Studies. Oxon: Routledge.

Rusman Adsyah. (1995). Terjemahan Juzu’ Amma Secara Harfiah. Kuala Lumpur: Darul Nu'man.

Sejarah Jakim. (2015). Dalam JAKIM; Jabatan Kemajuan Islam Malaysia. Dicapai pada 25 Julai 2016, daripada http://www.islam.gov.my/mengenaijakim/profil-jakim/sejarah

Tafsir al-Quran. (2015). Dalam E-Fatwa. Dicapai pada 1 November 2015, daripada http://www.e-atwa.gov.my/fatwa-negeri/tafsir-al-quran-0

Tafsir Ar-Rahman dalam Bentuk Baru (18 Ogos 1998). Utusan Malaysia Online. Dicapai daripada http://wwl.utusan.com.my/utusan.

Wan Ramizah Binti Hassan. (2000). Sumbangan Sheikh Abdullah Basmeih dalam Bidang Tafsir: Kajian Khusus Terhadap Kitab Tafsir Pimpinan Ar-Rahman.

(Disertasi sarjana). Universiti Malaya, Kuala Lumpur, Malaysia

Wherry, E.M. (1882/2001). A Comprehensive Commentary On The Quran: Comprising Sale's Translation and Preliminary Discourse. Jilid 1, London: Routledge.

Al-Zarqani, Muhammad Abd Al Azim. (1988). Manahil Al Irfan fi Ulmum alQuran. Beirut: Dar Al Kutub Al Ilmiah.

Zaini Nasohah. (2005). Undang-Undang Penguatkuasaan Fatwa di Malaysia. Islamiyyat. 27(1), 25-44.

Zulkifly bin Muda \& Nizaita binti Omar. (2010). Pemantapan Perpaduan Bangsa Melalui Pengaplikasian Kaedah Fikah. Prosiding Persidangan Nasional Paradigma Baru Perpaduan Bangsa (hlm: 93-111), Kuala Lumpur, Malaysia: Majlis Profesor Negara 